\title{
Review Article: Ancient Galilee and the realities of the Roman Empire
}

\begin{abstract}
Author:
Markus Cromhout ${ }^{1}$

Affiliation:

${ }^{1}$ Department of New

Testament and Early Christian

Studies, University of South

Africa, South Africa

Note:

This article was re-published with the corrected affiliation of the author.

Correspondence to:

Markus Cromhout

Email:

cromhm@unisa.ac.za

Postal address:

PO Box 1078, Sunninghill

2157, South Africa

Dates:

Received: 07 Dec. 2011

Accepted: 17 Sept. 2012

Published: 05 Nov. 2012

Re-published: 09 Nov. 2012

How to cite this article: Cromhout, M., 2012, 'Review Article: Ancient Galilee and the realities of the Roman Empire', HTS Teologiese Studies/Theological Studies 68(1), Art. \#1203, 12 pages. http://dx.doi.org/10.4102/ hts.v68i1.1203
\end{abstract}

C 2012. The Authors. Licensee: AOSIS OpenJournals. This work is licensed under the Creative Commons Attribution License.
This review article summarises and delivers comment on Religion, ethnicity and identity in Ancient Galilee: A region in transition, edited by Jürgen Zangenberg, Harold W. Attridge and Dale B. Martin and published by Mohr Siebeck in 2007. The majority of the articles in this volume testify of a 'Jewish' or rather Judean Galilee in the 1st century. It was a region that had cultural, economic, social, political and religious contact with surrounding areas and was thoroughly integrated into the realities of the Roman Empire. Whilst interregional contact and trade occurred freely, resistance and conflict occurred due to the proximity of 'the Other' that threatened the cultural and religio-political sensitivities of the Galileans. The Galileans also had strong attachments to aspects of their Judean identity, as evidenced by their enhanced musical culture, conservative epigraphic habit, participation in the revolt and the following of cultural practices also found in Judea. Based on this collection of articles, there are a few areas that need further investigation: how and when did the region fall under Hasmonean control and what was the exact nature of the local population at that time? At the time of Antipas, were Galilean peasants generally experiencing harsh economic conditions, or did his rule allow for economic participation to flourish? The exact context of Jesus' ministry, therefore, is still a matter to be decided and invites further investigation.

\section{Introduction}

This review article summarises and delivers comment on Religion, ethnicity and identity in Ancient Galilee: A region in transition, edited by Zangenberg, Attridge and Martin and published by Mohr Siebeck in 2007. The article places a special focus on issues that relate to the 1st century CE. The book reports on a research project sponsored by the Alexander von Humboldt Foundation and Yale University from 2002 to 2006 and boasts contributions from various international scholars. Zangenberg (2007) offers an introductory essay and summary of the articles (pp. 1-10), and he writes that the volume attempts 'to document different, sometimes conflicting approaches to the material and a variety of conclusions, because careful case studies better represent the current state of research than a premature synthesis' (p. 3).

The volume is divided into four main parts: Part 1: The state of affairs in Galilean studies; Part 2: What is a Galilean? Modes of defining religion, ethnicity and identity in textual and archaeological sources; Part 3: Identity at ground level: New evidence from sites and regions of Galilee; and Part 4: A region of many identities: Cultural interaction and social relations in and with ancient Galilee.

\section{Part 1: The state of affairs in Galilean studies Sean Freyne}

\section{'Galilean studies: Old issues and new questions' (pp. 13-29)}

It is perhaps quite appropriate that Freyne writes the first chapter in this collection, being one of the foremost scholars on Galilee in recent times (cf. Freyne 1988, 2001, 2004). His study draws on archaeology and what it can tell us about the process of Hellenization and Judaization in Galilee.

At first, he focuses on two sites in Upper Galilee: the cult center of Mispey Yamim in the Meiron massif and the administrative building that delivered a cache of seals from Kedesh. For Freyne, 1 Maccabees does not give reliable information about Galilee's inhabitants and cultural ethos in the pre-Maccabean period (mid-2nd century). Both sites were occupied during the Persian period and ceased to function in the middle of the 2nd century BCE. Both also give evidence of Phoenician and Egyptian cultic influence, whilst Greek influence is limited to Kedesh. Overall the evidence suggests for Freyne that Hellenization in Galilee was not imposed by either the Ptolemies or Seleucids, and no easy syncretism existed. What is evidenced is a native religious conservatism that was shared by all peoples of the East, including the Jews, ${ }^{1}$ at least in early encounters with

1.What Freyne describes as 'native religious conservatism' is somewhat anachronistic. In antiquity it is better described as an ethnic conservatism. On the anachronistic description of 'Jews' that practiced a 'religion' called 'Judaism', see Pilch (1997), Esler (2003), Mason (2009) and Cromhout (2007, 2010). Religion also did not exist as an independent area of life but was embedded in the realms of politics and kinship (Malina 1994). 
Hellenisation, yet this did not preclude wider contact and interaction in everyday affairs (p. 19).

When it comes to the military campaigns of the Hasmoneans, which aimed at recovering the land, the literary and archaeological evidence appear to corroborate one another. For Freyne, the Maccabean campaigns were informed by the following Jewish ideological perspectives:

(1) concern for 'the land not conquered', that is, not occupied according to Jos 13:1-6, leading to hostility towards the nations roundabout; (2) the failure of various tribes to destroy Canaanite cities in their allotted territories (Judges 1); and (3) the destruction of the pagan shrines within the land according to the Deuteronomic legislation (2 Kgs 23:15-20). (p. 24)

Alongside the militant nationalism of the books of Maccabees (derived from Joshua and Judges), we also find a pacific and universalist attitude (Genesis Apocryphon, Jubilees) derived from Genesis (Gn 13:14-17).

Freyne also discusses the uncertainties that exist about the incorporation of Galilee into the Judean state. He argues that neither Josephus (Ant. 13.318-19; traditionally read as the enforced circumcision of the inhabitants of Galilee by Aristobulos) nor his sources (Timagenes cited by Strabo) refer to Galilee or to a military conquest of Galilee. ${ }^{3}$ Freyne insists:

One task for future students of Galilee will surely be to refine the theories of its Judaization and see the ways in which our ideas of Galilee's incorporation into the Judean state as a form of 'ethnic cleansing' would seem to be in need of considerable modification. (p. 26)

Even if the conditions of Galilee's incorporation in the Judean state are uncertain, the influx of Hasmonean settlers is evidenced from the middle of 2nd century BCE to the Roman period by the growth in number of settlements and the corresponding industries of fishing, pottery making, the mass production of olive oil and other cultural features (stone jars, miquaot, absence of pig bones and burial practices). Pottery evidence from the 1st century CE also suggest a heightened conservatism and group solidarity, or a change in diet and towards communal dining practices when compared with the previous century, something that can be seen as a reaction to the Romanisation of the Galilee (pp. 28-29). The Jesus movement in Galilee, so Freyne suggests, is, however, indicative of a more tolerant and open attitude to the nations.

What Freyne highlights is the 'Jewish' nature of Galilee in the 1st century $\mathrm{CE}$, its conservatism, but also the possible existence of an openness towards Gentiles amongst its 'Jewish' population. We can ask to what extent this 'openness' required

2.See also Freyne (2001:299-301, 2004:79-82)

3.A position recently advanced by Horsley $(1995,1996$, cf. Horsley \& Draper 1999). The passage from Josephus refers to war being made against the Itureans by Aristobulus I, and Horsley suggests that part of the territory acquired by the Hasmoneans was a part of Galilee. Subsequently, Horsley argues, the Galieans (as descendents of a part of Gallee. Subsequenty, Horsley argues, the Galleans (as descendents of Northern Istalites) argues that the evidence does not support Iturean settlements in Upper Galilee and is therefore doubtful that Joshus is describing events that occured in Galile. is therefore Chancey $(2002.36,43-47)$ suggests that, at this stage, the Galilean population was a mixture of Itureans, Phoenicians and 'Jews', but also that Galilee was sparsely populated before the Hasmoneans took control of the region. a sacrifice of Jewish identity in a conservative (shall we say 'primordial'4) context? Can this 'openness' be identified somehow in the archaeological record? Freyne also brings focus to a burning issue: how did the Hasmoneans take control of Galilee? What was the nature of the local population at the time? As he correctly suggests, future research must endeavour to answer this question.

\section{Part 2: 'What is a Galilean?' Modes of defining religion, ethnicity and identity in textual and archaeological sources Martin Karrer}

'Licht über dem Galiläa der Völker: Die Fortschreibung von Jes 9:1-2 in der LXX' (pp. 33-53)

Karrer places the translator of Isaiah into Greek (the LXX) within the context of the power struggle between the Ptolemies and the Seleucids over Judea and the Maccabean liberation of Jerusalem in the first half of the 2nd century BCE. He bases this approach on the modification of the text in Isaiah 19:23 ('the Egyptians shall serve the Assyrians') and in light of this offers his own approach to the interpretation of Isaiah 9:1-2 (LXX). The differences between the MT and LXX lead him to the following hypothesis: 'Prophetie darf in der Septuaginta aktualisiert werden' [Prophecy can be updated in the Septuagint - own translation] (p. 37), something he also affirms for Isaiah later (p. 52).

Isaiah 9:1-2 (LXX) contains geographical names through which the remainder of the Israelites along the coast, those beyond the Jordan, as well as the 'Galilee of the Gentiles' (which at this time had a mixed population according to Karrer) are placed within an eschatological context where unfulfilled promises can be experienced. Using motifs of the Exodus, the text speaks of a road to Jerusalem or Judah for the northern tribes, including the Gentiles of Galilee. In this regard, the Isaiah (LXX) text is different from others (Jos 12:23; 1 Macc 5:15; Joel $3: 4$ [LXX]) in that the region is not rejected, and the promise of salvation is also applicable to the Gentiles, a motif also found in other parts of Isaiah (2:2-3; 62:1-2). It also differs from the Maccabean perspective of military campaigns and conquest originating from Jerusalem (pp. 49-50).

In this way, due to the road by the sea (Via Maris) and the road to the Transjordan, Galilee becomes a transit area ('Durchzugsgebiet') for northern Israelites for the eschatological departure and pilgrimage towards Zion. At the same time Galilee was a symbol for gentiles:

Nehmen wir beides zusammen, scheint das Licht über dem Galiläa der Völker als Signal für alle Völker, auf es zu schauen und sich aus dem Dunkel einer toten Gottesferne zu dem einen Gott Jerusalem-Judäas aufzumachen. [If we look at both these facts, the light over Galilee of the Gentiles shines as a signal for all peoples, to look at it (Galilee) and to come out of the deadly alienation from God to the same God of Jerusalem-Judah] (p. 51, [authors own translation])

4.According to ethnicity theory, 'primordialism' refers to strong psychological and emotional attachments by social actors to aspects of their ethnic identity (cf. Cromhout 2007:83-88). 
The article is of course not so much about Galilee itself as it is about a Judean perspective on Galilee at the time of early Hasmonean successes. Karrer assumes, somewhat problematically, that Galilee at this time had a mostly Gentile (but mixed) population, which is uncertain since the archaeological evidence for this period is either incomplete or testify to low population figures (Reed 2000:35-39; Chancey 2002:36). ${ }^{5}$ Whatever the situation, the translator of Isaiah did not see the occupation of Galilee as an integral expression of Judean identity.

\section{Timothy L. Marquis}

\section{'Re-presenting Galilean identity: Josephus's use of 1 Maccabees 10:25-45 and the term loudaios' (pp. 55-67)}

Marquis' aim is to investigate Josephus' use of historical sources and the reason behind his alterations of the accounts, in this way giving insight to Josephus' social and ideological interests (self-presentation). For Marquis, Josephus' alterations to 1 Maccabees 10:25-45 (Ant. 13.48-57), which contains a letter of the Seleucid king Demetrius I to Jonathan and where Josephus places Samaria, Galilee and Peraea under the authority of the Judean high priest, the law and the temple (Marquis [p. 66] sees Galilean subjection to the temple as contrived), indicates that Josephus wanted to make Samaria and Galilee, at least as far back as the Hasmonean period, appear more 'Judean' (p. 59).

Marquis relies cautiously on Spivak's (1994) work on portrayals by intellectuals of subaltern social groups, especially her notion of 'representation' as 'speaking for' (German vertreten; 'to stand in for') and 're-presentation' (darstellen; 'to describe') as in art or philosophy. Marquis is interested in how outsiders ideologically 're-present' subaltern classes as forming a unified and communal subjectivity (p. 61). He performs this analytical approach within the context of xenia relations (aristocratic networks of personal allegiance) amongst Judean ruling classes, something which for Marquis is prevalent in Josephus' description of social dealings. Xenia relations refer to representatives of a nation and the mutual loyalty between them and the people that is required in order to be accepted by foreign peers, offset by the reality that xenia relations with foreigners can erode that loyalty (p. 63). Josephus portrays himself as living within such a tension, that is, as a legitimate ruler of Galilee by describing his own loyal adherence to Judean customs. Galileans themselves is 're-presented' as 'Judean', whilst in other places (e.g. Vita 134-135) Josephus portrays himself as appealing to the needs of xenoi (foreigners).

What does this mean for Galilean identity? Marquis notes that Ioudaioi is translated as 'Judean' and 'Jew(ish)', where the former normally refers to an inhabitant of Judea and the latter to a trans-local religion or ethnicity. He also notes correctly that a Roman or Egyptian is known as such no matter where he lives and that the dual English terms for Ioudaioi are 'unique' when describing ancient groups. Though 5.See also footnote 3 above.
Marquis insists consistently that we should use the terms 'Jew' and 'Jewish', he offers no solution to this problem, apart from the vague suggestion that we should not ask how, but in what ways Galilee was Jewish or Judean. For him, the issue is not the problem of scholarship's 'terminological slippage'. Rather, he is interested in the opportunities with which 'terminological slippage' in Josephus' own writings present us 'those places where the term Ioudaios doesn't quite fit' (p. 67). By inference, Marquis speaks here of Josephus' own selfpresentation as belonging to the Jud(a)ean leadership.

Marquis' analysis highlights the anachronistic usage of 'Jews' or 'Jewish'. Israelites of antiquity with ethnic attachments to Judea must be referred to as Jud(a)eans, not 'Jews', no matter where they lived (Esler 2003:67-72; cf. Pilch 1997; Mason 2009:141-184). ${ }^{6}$ Galileans, therefore, were ethnic Judeans. What Marquis does not take into account is that most, if not all, social actors possess more than one ethnic identity and can form a sub-identity (e.g. Galilean), which is nested in a superordinate or more encompassing identity (e.g. Israelite or Jud(a)ean) (cf. Cromhout 2008). ${ }^{7}$ As a result, Josephus' 're-presentation' of the Galileans as Ioudaios, as advanced by Marquis, is questionable.

\section{Silvia Cappelletti}

\section{'Non-Jewish authors on Galilee' (pp. 70-81)}

What knowledge did the Greco-Roman world have of Galilee? In this investigation, Cappelletti sifts through ancient documents to answer this question and provides extensive quotations (in Greek and Latin) from various sources in the footnotes.

The first references to Galilee are found in the 1st century BCE in the writings of Cassius and Alexander Polyhistor, and the first real description of the region is encountered in Book 16 of Strabo's Geography. Other writings which Cappelletti mentions are Pliny (Naturalis Historia 5.66-73), Tacitus (Histories 5; Annals 12) and Ptolemy (Geography), whilst later sources add nothing new. Overall Cappelletti concludes, perhaps not surprisingly, that the information in these sources, which he separates into geographic and ethno-political categories, provide scant information and is highly inaccurate (pp. 80-81). Most of the geographic information concentrate on the Jordan Valley, its upper reaches, the river banks and the two lakes but serve as introductory information for the main subjects, namely the Dead Sea, Judea and Jerusalem. Demographic information is basically non-existent, apart from Strabo who wrote that Galilee had a 'mixed population'. As for Galilee's economics, Strabo mentions the lake's abundant fish, otherwise authors are not aware of a prosperous economy in the region. Lastly, as for the political situation, here too the information is inaccurate. Tacitus provides the exception as he gives accurate information in this regard: 'In the eyes of the Roman world, Galilee was a marginal region' (p. 81).

6.Elliott (2007) forcefully argued that where loudaiois appears 'Judaean' is the appropriate translation and not 'Jew' but he takes it further and suggests that we should rather use the preferred insider (emic) nomenclature of self-identification ('Israel(ites)', 'House/children of Israel')

7.In ethnicity theory, this is known as 'situationalism'. See footnote 13. 


\section{Mark A. Chancey}

\section{'The epigraphic habit of Hellenistic and Roman Galilee' (pp. 84-98)}

Chancey investigates inscriptions that were found in Galilee (up and until the beginning of the 4th century CE) through what he describes as the lens of the 'epigraphic habit'. The latter term, coined by MacMullen:

encompasses such issues as the types of inscriptions engraved; the languages chosen for various types; the events, facts, and ideas recorded epigraphically; the functions served by inscriptions; the places chosen for the erection of inscriptions; chronological variations in the frequency of inscriptions; the parties that commissioned and created inscriptions; and the parties reflected by and recorded in inscriptions. (p. 84)

In the Hellenistic period (323-363 BCE), most inscriptions were found on coins and amphora handles. Coins were mostly in Greek, but many Hasmonean issues are bilingual with Greek on the one side and Aramaic or Hebrew on the other. At this stage, all coins were struck outside of Galilee. The meagre evidence suggests that Hellenistic Galilee did not have much of an epigraphic habit.

This situation changes, however, in the Roman period. Apart from a few local issues, most coins were minted outside the region, and in Greek. Non-numismatic inscriptions demonstrate a steady increase in number as the Roman period progressed but with few examples that can be dated to the 1st century. The language of choice is Greek, with local languages being rare, but most of the ostraca are in Semitic languages. ${ }^{8}$ Chancey then suggests that, since Greek was the epigraphic norm:

any use of Aramaic or Hebrew in an inscription reflected an adaptation of Roman epigraphic culture, one that allowed both participation in this aspect of the broader Empire's culture and the expression of a distinctive local and ethnic (Jewish) identity. (p. 88)

Except for coins, burial inscriptions were the single most common type in Roman Galilee.

Chancey also reviews other evidence from the region and remarks importantly that the 'lack of epigraphic evidence for non-Jewish cultic practices is important support for the argument that Galilee was predominantly Jewish ...' (p. 91). ${ }^{9}$ At the same time, however, few inscriptions are identifiably Jewish, with the exception of the burial practices at Beth She'arim that make mention of synagogue officials, the title 'rabbi' and the afterlife and that have Jewish symbols.

Chancey sees a parallel between Galilee and Jerusalem's evidence. Little monumental epigraphy and few building, honorific and euergetistic inscriptions characterise both, perhaps showing a tendency to reject some aspects of Greco-

8.It is commonly recognised that Aramaic was the common language of Judeans, including Galileans, but also that a strong level of bilingualism (the use of Aramaic and Greek) existed. The use of Hebrew was not widespread (cf. Hengel 1989; Porter 1994:133; Horsley 1995:248).

9.Elsewhere Chancey $(2002: 117-119,165)$ argued against the idea of many Gentiles being present in Galilee in the 1st century CE.
Roman euergetism. ${ }^{10}$ Indeed, Chancey interprets the lack of Galilean inscriptions to suggest that, apart from the elites, Galilean society rejected this dimension of Romanisation and is a form of indigenous resistance to the dominant imperial culture (pp. 93-94).

For Chancey, therefore, the meagre evidence suggests the expression of a local and distinctive identity, as well as resistance to Romanisation.

\section{Michael Peppard}

\section{'Personal names and ethnic hybridity in late ancient Galilee: The data from Beth She'arim' (pp. 99-113)}

Peppard offers us a study in how the use of personal names may represent ethnic identity from the vantage point of ethnic hybridity, especially so within multi-ethnic contexts. Hybridity presupposes mixture and change, where personal names are used and adapted according to various social situations. Identity, in contrast, connotes sameness and stability. For example, an Israeli citizen may go by the name 'Yitzchak' with some people but 'Isaac' with others, or a Mexican-American can choose the name 'Hope' in place of her Spanish name 'Esperanza'. 'Names, like other symbolic systems, do not mean in isolation; they only make meaning in relationships, and only approach stable meanings in particular interpretive communities' (p. 101).

Peppard then discusses the insights of ethnicity theory (pp. 102-103) and wisely opts for a middle road between the primordialist and instrumentalist approaches towards ethnicity. ${ }^{11}$ He gives priority to language and consciousness of common descent as relevant cultural criteria of ethnicity since names represent the most common linguistic attachment and often manifest a consciousness of common descent. ${ }^{12}$ Primordialism looks at what a name represents, that is, an identity already given. Instrumentalism looks at what the name does, where it is performed anew and enacted in circumstances of everyday life. 'In short, personal names both represent and create what may be called a "constructed primordiality"' (pp. 103-104), that is, they both represent and create ethnicity.

Peppard's study focuses on funerary inscriptions at Beth She'arim, a cemetery to which Jews from all over the Diaspora brought their dead. He postulates a thesis that the data from Beth She'arim 'allow us to see a part of Galilee in late antiquity that was ethnically characterized by hybridity' (p. 106). He uses three criteria, namely, the 'language of presentation', the linguistic etymology or affiliation of each

10.Euergetism refers to the practice of city elites making donations for various purposes of public benefaction (e.g. construction of buildings, public entertainment, donation of food, etc.).

11.Primordialism and instrumentalism (as part of the reconstructionist approach) were often portrayed as being mutually exclusive. Primordialism looks at the strong emotional attachments to ethnic identity by social actors themselves, who experience their identity as 'fixed', 'sacred', or 'involuntary'. Constructionist approached understands ethnicity as socially (re)constructed and as fluid and freely approached understands ethnicity as socially (re)constructed and as fluid and freely chosen (Cromhout 2007:83-88). Fenton (2003:90) remarks that it is perfectly possible to have a conception of ethnic identity which allows us to see them ... as being constituted by elements which are civic, instrumental, circumstantial and
primordial.'

12.Ethnicity theory normally acknowledges kinship relations, myths of common ancestry and a connection to a homeland as key ethnic features (Duling 2005:127; Esler 2003:44) 
name and the relationship between these two. The most common language of presentation was Greek (78\%), whilst Semitic languages had the strongest linguistic affiliation (44\%). Peppard's study, however, is focused on about $10 \%$ of the inscriptions that clearly represent and create hybrid ethnicities, that is, names that cannot easily be placed into one category (pp. 107-108). These include names that have phonetic resemblances in various languages (e.g. Shime'on or Simon) and that can function in multiple ethnic and linguistic contexts. Also dual names, where, for example, a woman is named Isther (Esther) and Amphaitha (derived from a verb that means 'to give light'), that suggests the name Esther was equated with the Greek aster, 'star or light'. So through their onomastic expression, 'many of these people chose to both represent and create their ethnic hybridity' (pp. 113).

A few observations are in order. Most of the inscriptions at Beth She'arim date to the 3rd century CE and later (Chancey 2002:109). Secondly, probably most of the dead buried there were not Galileans. What can this evidence tell us about Galilean identity itself? Thirdly, Peppard's use of ethnicity theory is to be applauded; it is just its application here that is uncertain. More fruitful for his study on ethnic hybridity would have been variant approaches of instrumentalism known as 'situational' and 'circumstantial' approaches. ${ }^{13}$ Overall, it is to be questioned whether hybrid names necessarily imply ethnic hybridity. Says who? Here we need to distinguish between emic (insider) and etic (outsider) perspectives of the data. ${ }^{14}$

\section{Mordechai Aviam}

\section{'Distribution maps of archaeological data from the Galilee: An attempt to establish zones indicative of ethnicity and religious affiliation' (pp. 116-132)}

Aviam's study aims, by looking at the archaeological finds from the Hellenistic, Roman and Byzantine periods in Galilee, to identify their places of origin and distribution and then to draw some conclusions on how it can help define population zones relevant to ethnicity and religious affiliation. Aviam provides the greatest of services to scholars interested in Galilean studies as he provides numerous maps of Galilee that clarify the positions of archaeological finds. The study performs an overview of Galilean course ware (clay pottery produced by the local 'pagan' population in northern Galilee), Hasmonean coins, ritual baths, stone vessels, 'pagan' temples and Jewish synagogues, human statues and figurines, decorated sarcophagi (including ossuaries) and secret hideaways.

For each of these, Aviam gives a brief overview which he then compares with borders as attested in Jewish textual sources, namely, the 'Baraita of the Boundaries of Eretz-Israel', the

13.Strictly speaking, instrumentalism sees an ethnic group's self-construction as rational, self-interested and consciously mobilised in an attempt to further its own political-economic agenda. That is, ethnic identity functions as a sort of 'interest group'. Variant approaches are known as 'circumstantial' and 'situational'. The 'circumstantial' approach sees ethnic identity as important in some contexts but not in others. Although the identity remains constant, whether it matters or not is determined by circumstances. The 'situational' perspective explains that identity is expressed in different ways as the social situations of the individual change. This is especially relevant where social actors possess more than one ethnic identity (cf. Cromhout 2007:85).

14.The question is whether Judeans themselves (an emic perspective) would see their use of Greek names (of whatever variety) as ethnic hybridity. Language was not a critical identity marker for Judeans in the 1st century CE, so the use of Greek in a critical identity marker for Judeans in the 1st century CE, so the use of Greek in
various forms (e.g. the Septuagint comes to mind) was as much an expression of various forms (e.g. the Septuagint comes to mind) was as much
Judean identity as was the adherence to ancestral customs.
Mishnah (m.'Arak. 9:2), Josephus (War 3.1) and the names of rabbis and priestly courses found in the Mishnah and Talmud. These descriptions are also accompanied by maps. Aviam argues that there is:

a complete overlap between the two groups of data - archaeology and history ... The Galilee from the 2nd c. [BCE] to the 4th c. $[C E]$ was inhabited mainly by Jews living in villages, towns, and cities. (p. 132)

It is of note that Aviam argues that the practice of secondary burial (ossilegium) did not arrive in Galilee until the mid 2nd-century CE. Although 30 sites with ossuaries have been found, no 'clean' 1st-century tomb with ossuaries have been found (p. 126). Overall the article is well illustrated. The only drawback for New Testament specialists, perhaps, is that the maps locate areas spanning several centuries and do not depict the situation as it existed in the 1st century.

\section{Milton Moreland}

\section{'The inhabitants of Galilee in the Hellenistic and Early Roman Period' (pp. 133-159)}

Moreland attempts to investigate the origins and selfidentification of the majority of the inhabitants of Galilee, stretching from the Persian to the Early Roman period, utilising archaeological evidence. Quite early in his chapter, he argues that the presence of:

Jewish ethnic markers [stone vessels, miqva'ot, lack of pork bones, secondary burial - M.C.] does not mandate a Judean origin for the majority of its inhabitants during the [Early Roman] period [perhaps some, see 2007:138, 142, 157]. Rather, we should explore the socio-economic and political circumstances that led some [Early Roman] inhabitants of Galilee to these cultural, religious or ethnic orienting practices. (p. 134).

For Moreland, Galilee had cross-cultural ties and socioeconomic contact with the coastal region, and he questions isolationist models.

He also cautions that material culture remains do not necessarily provide clear evidence for ethnic and religious identity or geopolitical and ethno-religious borders. What is called for, 'is a richly textured description of the relevant material culture remains' that takes into consideration various factors (e.g. class and economic status) (p. 136). He agrees with other scholars that Galilee was 'Jewish' (consisting of people who identified with Judaism), but the term must be defined carefully: is it an ethnic, geo-political, religious or cultural category?, Moreland asks. ${ }^{15}$

A 'weak' connection with Judea is also evident for Moreland in that the vast majority of the Galileans were agrarian villagers who do not appear to have been interested in the purity concerns (stone vessels, stepped pools) within Judaism. Neither do we find stone ossuaries for secondary burial. ${ }^{16}$

15.We must insist that 'Jewish' is anachronistic, and the correct translation 'Judean' is an ethnic category that encompasses all aspects of Judean identity. See also footnote 1 above.

16.Contrast the view of Reed (2000:44-51, 1999:95-102) that the archeological remains in Galilean domestic or private space are the same as that in Judea. He mentions limestone vessels, stepped pools, secondary burial practices and bone profiles that lack pork. Chancey $(2002: 165)$ also indicates that the archeological profiles that lack pork. Chancey (2002:165) also indicates that the archeological
profile of Galilee is in glaring contrast to the surrounding regions where there is abundant evidence for gentile populations. 
So who were the inhabitants then, we may ask? According to Moreland, the resettlement of Galilee began prior to the Persian period with Tyrian-led Syro-Phoenician cities along the coastal plain. With time, inland rural settlements emerged (p. 142). He then performs an extensive survey of Western and Northern Galilee and the occupation patterns influenced by Tel Acco or Ptolemais, as well as Upper Galilee and the Golan (e.g. Tel Anafa and Tel Kedesh), which in various ways display Hellenistic and Syro-Phoenician influence. The exceptions were the Itureans (upper Golan) and 'Jewish' Gamla, and there was a strong 'Jewish' influx (new arrivals and/or 'converts') in the Early Roman phase of settlement. Overall, the Hasmonean 'borders' (late Hellenistic period) cannot be used to argue that 'Jews' of Galilee of the Early Roman period were clearly distinguishable from the Syro-Phoenicians. In fact, Moreland argues that, throughout the Persian and Hellenistic periods, many inhabitants of Galilee were 'likely either Syro-Phoenician or they were tied in one way or another to Syro-Phoenician economic interests ...' (p. 157).

Moreland describes this essay as an 'initial probe' that will lead to a full excavation season. For the greater part, his study targets the extreme western and northern border regions, so one must wonder how his conclusions, preliminary as they are, adequately describe the heartland of Galilee, or the origin of most of its inhabitants that are (justifiably) identified by scholars as Judeans who settled here during the Hasmonean expansion to the north. ${ }^{17}$ This is the generally accepted picture based on archaeological finds. We will have to wait for his excavation results to see if any evidence to the contrary exists.

\section{Part 3: Identity at ground level: New evidence from sites and regions of Galilee Wolfgang Zwickel}

\section{'The Huleh Valley from the Iron Age to the Muslim Period' (pp. 163-192)}

Zwickel notes that the Huleh Valley is 'archaeologically amongst the least explored regions in present day Israel' ( $p$. 163). Situated in the northern Jordan valley between Mount Hermon in the north and the decline towards the Sea of Galilee in the south, it boasts some important sites such as Hazor, Dan and Caesarea Philippi.

Zwickel discusses the size of the lake in Josephus (the lake was drained in 1951-1958 by the Israelis), the marshlands north of it and the settlement patterns around them in Iron Age II, Persian, Hellenistic, Roman, Byzantine and Muslim Periods. He notes that, after a decline in the Persian Period, a significant increase in settlements occurred north of Lake Huleh during the Hellenistic period. They served as a food supply for cities on the coast like Tyre and Sidon and had direct road connections:

Even under the Hasmoneans the region remained under Tyrian control, since Hasmonean rule extended only to Lake Huleh

17. Reed $(2000: 40-41)$ also points out that the vast majority of stratigraphically excavated sites from the Roman-Byzantine Period have their earliest recoverable excavated sites from the Roman-Byzantine Period have their earliest recoverable
strata dated to the Late Hellenistic and Early Roman periods, that is, the 1st century strata dated to the Late
$\mathrm{BCE}$ and 1 st century $\mathrm{CE}$. and not further north. Thus, Lake Huleh constituted a cultural divider during the 1st c. [BCE] between areas under Judean and under Phoenician influence. (p. 179)

The pattern of settlement north of the lake intensified during the Roman Period, whilst some increase in settlements occurred to the south. The latter was situated in the extreme north of Herod Antipas' territory 'and was perhaps not considered worth a substantial investment' (p. 179), whilst the former was favoured by Philip (Zwickel: 'Philippus') because of trading with Damascus.

The same settlement pattern occurred during the Byzantine and Muslim periods. Zwickel also offers a useful table (p. 186-192) cataloguing the archaeological sites and the periods of which they are representative, whilst the various settlement phases are also indicated by several maps throughout the article.

\section{Carl Savage}

\section{'Supporting evidence for a first-century Bethsaida' (pp. 193-206)}

This article provides evidence of the occupation of Bethsaida (et-Tell) throughout the Hellenistic to shortly before the Byzantine period, especially during the 1st century CE. This appears to confirm Josephus' report of the city on the northern shore of the Sea of Galilee, next to the Jordan River in lower Gaulanitus (pp. 193-194). The claims are confirmed by various finds at Bethsaida, including coins, stamped amphora handles, glassware, ceramics, stone ware and faunal and architectural remains.

According to Savage, the site was destroyed in Iron Age II (Assyrian conquest in late 8th century BCE), but a sudden period of construction and reoccupation occurred during the Hellenistic period (3rd century BCE) under Ptolemaic and later Seleucid control. This came to an end during the campaign of John Hyrcanus I in the Golan (late 2nd century BCE) accompanied by a significant change in material culture, which is representative of the Hasmonean Kingdom. This settlement was followed by the city falling under Herodian control. What characterises all these transfers of power is that it occurred peacefully (p. 195).

Savage gives an overview of the archaeological evidence found at Bethsaida (coins, Rhodian stamped handles, glass, stone vessels, architecture, oil lamps, ceramics, faunal evidence [pp. 196-205]). Stone (and basalt) vessels along with other ethnic markers (e.g. paucity of pig bone, and pottery from Kfar Shikhin and Kfar Hananiah) suggest a 'Jewish' presence in 1st century Bethsaida, whilst miqva'ot, ossuaries and synagogues are not attested.

Savage notes that Bethsaida declined after the Hellenistic period. In the 1st century, it:

appears to be less wealthy, less orientated to the Phoenician coast and more orientated to the west and south - the Jewish Galilee - than the earlier Hellenistic period settlement. Further, in terms of its ethnic identity it shows elements of being a Jewish, not a Gentile, settlement, and therefore remains the most viable candidate for biblical Bethsaida. (p. 206) 
Savage's excavations create a different impression from earlier ones where it has been claimed that a Roman-style temple was found, suggesting that it was a centre for the Roman imperial cult (Arav \& Freund 1997; Arav, Freund \& Shroder 2000; Hengel 1989:16); this identification has, however, been questioned (Chancey 2002:108). All agree that Bethsaida was far more modest in wealth and stature than other Herodian cities, which begs the question: Why did Herod Philip rename the city to Julias (wife or daughter of Augustus?) in $30 \mathrm{CE}$ ?

\section{Yizhar Hirschfeld and Katharina Galor}

\section{'New excavations in Roman, Byzantine and early Islamic Tiberias' (pp. 207-229)}

This article reports on the first three seasons of a ten-year project at Tiberias conducted in March 2004 and April 2005. The city, founded by Herod Antipas in 18/19 BCE, is of great interest to scholars concerning its political, socio-economic and cultural impact on Galilee. ${ }^{18}$ After the death of Agrippa I (44 CE), it came under the control of Palestinian procurators, became a Jewish polis in $54 \mathrm{CE}$, and remained the capital of Galilee until 61 CE when Nero handed it over to Agrippa II. After his death around $100 \mathrm{CE}$, the city was incorporated into the Syrian province and placed under direct Roman control. With time, it became a major centre of Jewish life, and the Sanhedrin and the Patriarchate moved here from Sepphoris whilst the Great Academy (beth hamidrash ha-gadol), where the Jerusalem Talmud was compiled around 420 CE, was established there.

Hirschfield and Galor's excavations had three main foci: a bathhouse, the marketplace and the basilica. Plans are provided (p. 213), but the grey-scale legends are unfortunately not easy to follow. Otherwise the article has several black and white photos that accompany the explanations of what was found in the various strata (from 2nd century BCE to 11th century CE representing eight strata) as well as a proposed reconstruction of ancient Tiberias by Porotzky (p. 228).

What was uncovered from the 1st century were marble pavements, two water channels, walls and floors. Of no small significance to New Testament scholars is that the authors propose that they have uncovered an upper class residential or even palatial structure, suggesting that it was the palace of Herod Antipas. Fragments of painted and molded plaster, frescoes, Herodian-style ashlars, pieces of marble slabs, opus sectile tiles found together with pottery shards and other finds, they suggest, belong to the same architectural complex (pp. 214, 223). This is situated underneath a basilical complex dated from the 4 th century $\mathrm{CE}$ and discussed in greater detail (pp. 221-229). The authors suggest that:

the basilica was built right on top of the Herodian palace or its ruins; this is indicated by a fine but clear layer of ash potentially pointing to the destruction of Herod Antipas's residence during the First Revolt against the Romans. (p. 224)

18.This, of course, is also true of Sepphoris. Josephus' report of the Great Revolt is indicative that tense urban-rural relations existed in Galilee (cf. Reed 2000:66-93; Horsley 1995:215-221), yet the exact reasons are not clear. Was it for socioHorsley 1995:215-221), yet the exact reasons are not clear. Was it for socio-
economic, cultural or political reasons, or a combination of these? (cf. Cromhout 2007:249-260, 252-253)
Hopefully, further excavation will lead to more clarity as to whether this was indeed Antipas' palace.

\section{Anders Runesson}

'Architecture, conflict, and identity formation: Jews and Christians in Capernaum from the first to the sixth century' (pp. 231-257)

Runesson's study focuses on the relationship between the ancient synagogue and church found in Capernaum and the interaction between Jewish Christ-believers, the early church, as well as on the relationship of these groups with Judaism. He presents a thorough overview of the archaeological evidence of these buildings and offers a plausible reconstruction of their history as well as the social dynamics behind them. He argues that the limestone synagogue should be dated to the 5th century CE and was built re-using material of a previous building (spolia). He also accepts that a 1st-century synagogue of black basalt stone existed as attested by the Gospels, but this was much smaller in scale (pp. 235-239). ${ }^{19}$

The so-called house of Peter south of the synagogue is what he reviews next (pp. 240-243) and concludes that various phases are discernible. In the second half of the 1st century, a room (room 1) was used for community gatherings. In the late 4 th century, the complex was enclosed by a wall and transformed into a house church by Christ-believing Jews, as suggested by the level of continuity and sensitivity that lay behind its construction. In the second half of the 5th century, it was destroyed by Byzantine Christians and replaced by an octagonal church.

Runesson sees the 1st-century synagogue as a public synagogue, whilst the house of Peter (mentioned several times in the Gospel of Mark) was 'an early example of a meeting place for a Jewish Christ-believing association' (p. 246). With time, however, the nature of the population in Capernaum changed drastically with the non-Jewish population steadily increasing between the 1st and 5th centuries. The archaeological evidence seems to suggest that Jewish and non-Jewish Christ believers competed over the pilgrimage site. Indeed, the destruction of the house church indicates as much. At the same time (5th century), several restrictions were placed on the Jews by the politically empowered Christians who represented colonial power:

The limestone synagogue, then, may have been constructed - in accordance with the laws of the $5^{\text {th }} \mathrm{c}$. allowing for the repair and reconstruction of synagogues, if not building new ones - as a defiant act of defence against the colonizers, a reclaiming of a place in a town the Jews saw as theirs. (p. 252)

This was a reinforcement of Jewish identity, which in turn estranged Christ-believing Jews even more from their Jewish context:

and place them in a no-mans-land between rabbinic Judaism and Byzantine Christianity, relating their identity to both, while, at the same time, being despised and excluded by people in the power-centers of both. (pp. 253-254)

19.On the existence of the synagogue in Capernaum at the time of Jesus, see also Strange and Shanks (1990) and Chancey (2002:104) 


\section{Jodi Magness}

'Did Galilee decline in the fifth century? The synagogue at Chorazin reconsidered' (pp. 259-274)

In this article, Magness questions the claim that Palestine and, in particular, Galilee underwent a process of decline and regression in the 5th century, a view espoused by Ze'ev Safrai. She suggests that various synagogues (Khirbet Shema, Hammath Tiberias, Sepphoris, Gush Halav, Capernaum) were constructed between the late 4 th and the early 6th centuries. In this article, she investigates the synagogue at Chorazin.

The article is beautifully illustrated with illustrations and photographs. In the process, she argues that the numismatic (pp. 268-270) and ceramic (pp. 271-272) evidence suggest that the synagogue was constructed in the latter part of the 5th century or later. Magness also discusses literary evidence like Eusebius and other early Christian texts. ${ }^{20}$

\section{Part 4: 'A region of many identities': Cultural interaction and social relations in and with ancient Galilee Morten Hørning Jensen}

'Message and minting: The coins of Herod Antipas in their second temple context as a source for understanding the religio-political and socio-economic dynamics of early first century Galilee' (pp. 277-313)

Jensen notes that no consensus has been reached on Antipas' impact on Galilee:

Thus, an impasse has been reached concerning Herod Antipas as to whether he caused a deteriorating economic slide through monetization, inflation, and rising debts, or whether he evoked a period of peace, prosperity, and stability. (p. 278)

His study focuses on coins since it was used as a vehicle for religious and political propaganda and can provide insight into the socio-economic conditions that prevailed. Of special concern are copper coins, since a:

sudden demand for copper coinage, resulting in heavy minting, is likely to be an indicator of a rise in urbanization, implying specialized labor, a decline of self-sufficiency, and heavier monetization (p. 283).

Jensen performs his study within the context of Hasmonean coinage and also considers those of Herod the Great, Archelaos, Philip, Agrippa I and the Roman administration. For each of these, he gives a detailed and informative overview (pp. 283-295). As for the coins of Antipas (discussed in detail on pp. 295-309), they were generally rare but widely used in Galilee and the Golan. They were not provocative, they adhere to the Jewish aniconic tradition, and they show poor workmanship. Jensen also discusses a newly discovered coin that is attributed to Antipas but is made out as insignificant, a 'trial version' (pp. 295-296).

20.The archaeological evidence for synagogue buildings in 1st century CE Palestine is meager. There is the Theodotus inscription that clearly points to the existence of a synagogue in Jerusalem. Otherwise, the following sites have been identified as having synagogue buildings, although some are disputed: Masada, Herodium, as having synagogue buildings, although some are disputed: Masada, Herodium,
Caesarea, Jericho; and relevant to Galilee: Gamla (in the Golan close by), Capernaum, Chorazin and Migdal (Magdala) (cf. Cromhout 2007:171-172).
Overall, Antipas minted five series of coins in three groups, but there is no evidence of a drastic change in circulation, and the amount of coins minted by Antipas was modest. Hasmonean coins dominated everyday usage at this stage. The coins of Antipas:

are best described as modest, carefully adjusted, and slightly insignificant ... Antipas's coins were minted in fairly low numbers and more probably for political reasons [the founding of Tiberias, the pledge of kingship from Gaius, and the political contest with Pilate] than due to market concerns. (p. 312)

The numismatic evidence, as it bears on the socio-economic conditions of Galilee, therefore does not seem to support a 'picture of conflict', and Antipas' urbanisation 'could be absorbed within the level of monetization already present in early 1st c. Galilee' (p. 313).

This article challenges reconstructions of Galilee - and therefore the context of Jesus' ministry - as an area subject to intensified monetisation, severe debt and tax collection and the economic pressure and/or loss it supposedly brought about (e.g. foreclosure on land and tenant farming, day labourers, beggars and banditry). ${ }^{21}$ No doubt, this is an area that is in need of further research and clarification. That economic difficulties existed in Galilee (and Palestine) cannot be questioned (cf. Oakman 2008; Fiensy 1991), so what future research needs to establish is not the kind, but degree of debt, taxation and landless people in Galilee at the time of Antipas. Perhaps the conflicting evidence suggests that we need to accept a more nuanced view of economic realities in Galilee in that the realty of debt for some and relative prosperity for others ran parallel to each other.

\section{Marcus Sigismund}

'Small change? Coins and weights as a mirror of ethnic, religious and political identity in first and second century [CE] Tiberias' (pp. 315-336)

According to Sigismund, city coins and weights from Tiberias have attracted too little attention concerning issues of ethnicity and identity. What he offers here is an overview based on the available, yet fragmentary material uncovered thus far against Josephus' claim that Tiberias was initially populated by a 'promiscuous rabble' from all over Antipas' territory and was tainted by impurity because of its location on grave sites (Ant. 18.36-38).

The city coins focus understandably on Herodian and Roman coins with Sigismund giving readers a detailed overview of the coins of Herod Antipas, Agrippa I, Agrippa II and Roman Tiberias (pp. 320-331). His preliminary conclusions include the following: coins issued under Herod Antipas and Agrippa I bear witness to the Jewish character of Tiberias. Early Roman coins display imagery that is mostly neutral whilst a change in the 2nd century CE is observable, where the city experienced intensified Romanisation although most of the inhabitants remained Jewish.

21.Cf. Horsley (1995:218-219), who suggest that Galileans were subject to pay tribute to three layers of rulers: the Jerusalem temple, Herodians and Romans. Others who thave question (2004:26) who questioned a severe economic situation in Gallee are Richardson (2004:26) who notes that rural towns and villages increased in number and size at this period. Freyne (1988:165-166) also argues that the level of oppression in Galilee was not the same as in Judea. 
The second part of the study focuses on two weights found near Tiberias, preserving the names of agoranomoi (pp. 332-335). The first gives evidence of a highly Romanised Jew, or even a Roman, reading 'In the 34th year of Herod the tetrarch, agoranomos Gaius Julius'. The second has inscriptions on both sides. One side reads 'year 43 of the great king Agrippa (our) lord', dating to the period of Agrippa II (61/62 CE). The other side reads '(In the term of office of the) agoranomoi Isaias (son of) Matthias and Aianimos (son of) Monimos'. According to Sigismund, the first person appears to be a Jew whilst the second, although Semitic, was probably not.

Sigismund concludes that this fragmentary evidence seems to support Josephus that Tiberias started with a mixed population, but the numismatic evidence in terms of the city's 'public image' and 'official identity' testify of a Jewish identity, as aspired by its founder and the city itself. In the 2nd century $\mathrm{CE}$, the imagery began to communicate the increased Romanisation of the city.

Josephus' reference to Tiberias being populated by a 'promiscuous rabble' may reflect his experience of local opposition at the time of the revolt. Josephus also mentions that Antipas forced peasants to live in Tiberias and that, at the time of the revolt, there were 'Greeks' present (Life 132-48; War 2.598-610; 3.492, 500-501). This, when combined with the meagre evidence cited above, is perhaps not enough to conclude, or infer, that the city had a 'mixed population' (to what extent?), but it is a matter that will only be decided by more archaeological data.

\section{Monika Bernett}

'Roman imperial cult in the Galilee: Structures, functions, and dynamics' (pp. 337-356)

Bernett emphasises that the imperial cult was a religious and a political phenomenon and affected all areas of public life and space, a significance which should not be marginalised (p. 338). This also holds true for reconstructions of Judean and Galilean history as it helped to structure space, time and the symbolic world of the population. Bernett questions claims that Jews were exempted from participation in the imperial cult. She argues that, since no law existed to venerate the emperor, nobody needed exemption from it. Yet, the imperial cult as it developed under Augustus did pose a challenging new situation for Jews (p. 341). So, the presence of an imperial cult in Judea gives rise to the question whether 'its presence influenced and evoked new self-definitions of Jewishness and (non-Jewish) otherness' (p. 342).

The presence and political impact of the imperial cult on Galilee is Bernett's particular focus (pp. 342-353). What is investigated is Antipas' refounding of Sepphoris as Autokratoris, the establishment of Tiberias and buildings for sport and entertainment mentioned by Josephus (a stadium for athletic competitions and a hippodrome at Tarichaea). With one exception, Antipas refrained from making reference to the imperial cult in his coinage. Galileans were heavily involved in the resistance against Caligula's plans to erect a statue of himself in Jerusalem's temple. Agrippa I expressed his country's loyal relationship towards Rome and represented the imperial family and non-Jewish cults on his coinage. Eastern Galilee was added to Agrippa II's territory, and although we do not know how the Galilean Jews reacted to this political situation, they supported and actively participated in the Jewish revolt. Coinage issued by the Romans as well as Agrippa II also testify that there was a wide dissemination of the imperial cult (pp. 352-353). ${ }^{22}$

So, was the presence of the imperial cult one of the main reasons for the outbreak of the revolt? Bernett suggests that radical opposition against the imperial cult garnered increasing support over time and was part of the legitimisation strategy of the rebels. Slogans on rebel coins pointed to liberation or 'purification of everything not 'holy' and 'Jewish" (p. 355). How did this affect Galilee? Bernett sees evidence of its effects in the factional conflicts of Sepphoris and Tiberias but not so much between classes as between people holding different concepts of purity (p. 355). ${ }^{23}$ In the end, she concludes that the imperial cult in Galilee should be considered a contributing factor to a politicisation of the Jewish residents.

Nobody can argue with her conclusions, yet it always needs to be seen alongside the political, economic and social suffocation generally experienced under Roman rule, the local (elite) cooperation with that rule, as well as the dishonour of subjugation to the 'other'. ${ }^{24}$ The study could also have benefited from the insights of ethnicity and postcolonial theory, which inter alia investigate how identities react when under threat or experience foreign rule.

\section{Douglas R. Edwards}

\section{'Identity and social location in Roman Galilean villages' (pp. 357-374)}

Edwards' study focuses on Galilean villages and notes that claims of 'little traditions' surviving from the 8th century BCE are extremely unlikely. Villages are not long-lived static entities. Rather, what we see is a gap in settlement followed by many new settlements in the Persian, Hellenistic and Roman periods, accompanied by a change in material culture as well (pp. 359-362). ${ }^{25}$ Edwards also gives readers multiple maps and graphs of various surveys and studies indicating the settlement pattern of Galilee.

He also questions reconstructions of the 'political-economy' of Galilee and the interaction between urban elites and rural areas. Far from being passive recipients of economic control,

22. Bernett does not discuss the possible existence of an Augusteum that Herod the Great built in Omrit in far northern Galilee (cf. Overman, Olive \& Nelson 2003; Jacobson 2002:22). Josephus states, however, that none of the temples dedicated to Augustus (also constructed in Ceasarea and Sebaste) was built in Judean territory (Ant. 15.328-330, 363-364; War 1.403-407).

23.See also Stegemann and Stegemann (1999:182), who suggest that the Zealots were a group of radical priests who wanted to restore the purity of the temple in Jerusalem.

24.As Geertz (2000:264, 276) points out, primordial sentiments flourish in contexts of political suffocation and where there is a sense of political dismemberment. Human beings generally refuse to submit to another system in order not to submit to degradation. It is to refuse to be made out as a lesser order of being, as irrelevant, powerless and simple minded.

25.Similar arguments are advanced by Reed (2000:32-34) and Chancey (2002:34). 
what we find in villages are 'activities that indicate active engagement by villagers in the local and regional economy that belie direct involvement of local elites in the cities' (p. 363). Examples include pottery production, dovecotes, stone-vessel workshops, the fishing industry, basalt-vessel workshops, agrarian-based activities and construction work and artisans, all of which Edwards likens to 'smallscale entrepreneurs' (p. 367). This pattern of diversification, storage and redistribution was typical of all rural sites across the Early Roman empire, and Edwards contends that the stable rule of Herod Antipas allowed for diverse economic activities to flourish:

That some of this involved redistribution of land from independent farmers to large landholders seems plausible, although slight evidence exists for large land holdings by single individuals in Galilee proper (p. 368).

In terms of cultural markers, the Maccabean period brought significant changes (pottery, stone vessels and coins) and signified anti-Romanisation attitudes (pp. 370-373).

The picture of Galilee that Edwards reconstructs is one of a Jewish Galilee filled with people engaged in various economic activities, that is, actively engaged in the larger economic currents around them. Yet again, this view represents a challenge to reconstructions of a Galilee whose peasantry was crippled by debt or deemed helpless by the control of an urban elite. Yet one must question to what degree Galileans can be likened to 'small-scale entrepreneurs', without direct involvement of the local elites. For example, the fishing industry appears to have been controlled by the elite (Hanson 1997), and further research needs to determine whether this is true of other areas as well.

\section{Stuart S. Miller}

'Priests, purities, and the Jews of Galilee' (pp. 375-402)

This article is an investigation into the role of priests in Jewish society with a focus on the Amoraic and immediate postTalmudic eras. Miller explains that, contrary to interpretations of his earlier research, he in no way concluded that a large number of priests, or priestly courses, settled in Sepphoris in the 1st century (pp. 376-377). Also, arguments for a significant number of priests in Sepphoris and in Tiberias in the 3rd century CE are not compelling (pp. 381-382).

Miller sifts through various rabbinic texts and identifies that, after the Bar Kokhba period, funerary or dedicatory inscriptions that identify connections between an individual and a particular priestly course (mishmar) are not to be found. What we find instead is the identification with the kohanim as a whole and the sense of honour that came with it. The invoking of a specific priestly course only emerged in 3rd and 4th century plaques on synagogues and in the piyyutim, which were recited in the 6th and 7th centuries (pp. 388-389).

Yet overall, the evidence is too little to conclude that the priests were heavily involved in the synagogue and general Jewish community or that they experienced renewed authority and influence. ${ }^{26}$ Miller argues that when the evidence (synagogue mosaics, ceramics and inscriptions) is interpreted, scholars confuse interest in the Temple with priestly interests (p. 395). The latter:

would be kept alive by a larger community of Jews that understood that the role of the kohanim primarily belonged to the past and especially to the redemptive future, when it would once again be essential for the renewed worship of all Israel. (p. 401)

\section{Joshua E. Burns}

\section{'The archaeology of rabbinic literature and the study of Jewish-Christian relations in late antiquity: A methodological evaluation' (pp. 403-424)}

This study attempts, contrary to the arguments of Neusner (1984), to use the rabbinic literature as a source of history. Burns explains that the 'extraction of contemporary social realia from rabbinic literature may well be likened to a process of textual archaeology' (p. 411). Of interest are synoptic parallels and editorial activities of each redaction. Burns uses Tosefta 'Abod. Zar. 2:7 and its parallel in the Mishnah ('Abod. Zar. 1:7) as a test case.

Burns identifies the passages that are addressing Roman entertainment as a unit that bridges the two documents. In the Mishnah and Tosefta passages, the rulings concern public safety as it pertains to stadiums and similar Roman entertainment venues (pp. 417-419). The Tosefta passage in particular alludes to the hope that Jewish spectators could save a person's life whilst on trial before the Roman authorities.

So, what can it tell us about Jewish-Christian relationships? For Burns, there is a strong possibility that the ruling on Jewish spectators' behaviour was made in reference to the Roman persecution of Christians, something that was known to the compilers of the Tosefta (cf. t. Hul. 2:22, 24) (p. 422). The rabbis would have encountered Christianity in its Jewish form in Roman Palestine, and although the rabbis condemned sectarian behaviour, they 'did not attempt to disenfranchise the Jewish Christians, nor any of the minim, from the broader Jewish socio-religious polity' (p. 423).

\section{Mira Waner}

\section{'Music culture in Roman-Byzantine Sepphoris' (pp. 425-447)}

Waner offers a unique study as it investigates the musical aspects of Sepphoris using the multidisciplinary tools of archaeo-ethnomusicology (combines ethnicity, archaeology and music) in view of its multicultural environment and the issue of distinction versus syncretism amongst its ethnic or religious groups. The study focuses on the Roman and Byzantine periods.

26.This begs the question whether there was any form of developed leadership over Galilean 'Jews' after the Bar Kokhba period. According to Oppenheimer (2005), the tours of Rabban Gamaliel of Yavneh towards the end of the 1st century established the authority of the rabbinic leadership institutions over the Jewish population in Palestine. Apart from Yavneh, other major centres included Lod or Lydda and Joppa. Thereafter Usha and Beth Shearim (western Lower Galilee) became majo centres. Around $200 \mathrm{CE}$, Sepphoris and Tiberias rose to prominence for the sages. Horsley (1995:90-99, 181), however, questions whether the rabbis had any substantial influence or leadership roles at this period. Irrespective of whether the rabbis had influence or not, we must assume that many priests joined their ranks. 
Waner notes that Galilee had a multi-ethnic population from the 3rd to the 5th century, yet the cities were predominantly Jewish. Sepphoris in particular served as the 'administrative, religious, and cultural center for Jews of Israel and the Diaspora throughout much of this period' (p. 427).

The musical finds in Sepphoris include eight from the Roman and nine from the Byzantine period. Only two bells are actual instruments whilst the most are depicted on mosaics. Musical instruments are also found on an oil lamp, a copper seal and a bronze figurine. Aerophones make up the most instruments (58\%) followed by idiophones (26.3\%) (p. 428). Wane then provides a brief overview of all the musical finds: various bells, cymbals, auloi (wind instruments), syrinx, curved horns, ram's horns (shofarot), tympanum and lyres. One shofar appears in what is termed a 'symbolic grouping', namely, with a menorah, mahta, lulav and etrog (pp. 429-432, 436-446). What is helpful is that black and white photographs also depict the instruments (pp. 433-436).

Overall the musical finds illustrate that the inhabitants of Sepphoris were familiar with both Greek mythology and Jewish ritual. The Jewish people in particular perhaps felt no threat from 'the Other', since they did not find it necessary to invent their own musical culture. In terms of the manipulation of symbols to maintain ethnic boundaries, they enhanced their own musical culture in its traditional, symbolic aspects to maintain uniqueness and distinctiveness. At the same time, they showed syncretistic tendencies in other spheres, especially towards the 4 th century (pp. 455-456).

This is a welcome addition to our knowledge of Galilee, yet a problem with the above analysis is that an enhancement of their own musical culture gives grounds to argue that the Galileans did indeed feel threatened by 'the Other'. It is a typical reaction of ethnic groups to attach more significance to aspects of their culture when feeling this way (Scott 1990). In addition, ancient Mediterranean cultures were not so much about the invention of new things as it was about preserving ancestral customs (Malina \& Neyrey 1996:39, 2008; McVann 1993a, 1993b).

\section{Thomas M. Weber}

\section{'Gadara and the Galilee' (pp. 449-477)}

Weber notes that Gadara had an extraordinary position giving it the character of a frontier post. Josephus describes it as part of Galilee's eastern border (J.W. 3.35-40). It was simultaneously connected via roads with Acco or Ptolemais and with Caesarea Maritima and the Syrian hinterland to the east, integral for communication and exchange of merchandise (pp. 450-451).

Yet, there were cultural differences, as well as mutual antagonism between the regions west of the Galilean Lake and the Transjordan cities, as demonstrated by burial customs and historical sources. After the supposed conquest of Gadara by the Hasmoneans and the increase in Jewish settlement, most of the Gadarenes were reluctant to live under Jewish rule. The local Jewish population also appears to have participated in the Jewish Revolt that had led to a pogrom against Gadara's Jewish community (pp. 459-460).
Overall the picture is one of conflict and symbiosis. On the one hand, there was communication, exchange and cultural contact with the Galilee. Cultural contact with Galilee is evidenced by the presence of pottery from Kfar Hananiah and the presence of Galilean bowls. Weber also discusses the hot springs that were frequented by local Jews in nearby Emmatha, which also had a synagogue sponsored by Jews from the Galilee (pp. 474-476).

On the other hand, there is evidence of conflict and warfare such as a burnt temple of Zeus, probably destroyed by Jews at the early stage of the revolt and a hastily built imperial rampart. There are also Flavian Gates at Gadara and Tiberias, which appear to mark the starting points of a road that linked the two cities (pp. 461-469).

Weber also discusses an underground monumental tomb that was extended over a basilica in the early Byzantine period. Something similar was found in Capernaum and demonstrates a close familiarity with Roman funeral practices (pp. 469-474).

The article, which is beautifully illustrated with various drawings, photos, plans and elevations, gives readers insight into the interaction between Galilee and neighbouring cities, especially those with a Judean minority.

\section{Concluding remarks}

To summarise, the majority of the articles in this volume testify of a 'Jewish' or rather Judean Galilee in the 1st century. Those who argue to the contrary will have to demonstrate otherwise in a convincing fashion. Nevertheless, it was a region that had cultural, economic, social, political and religious contact with surrounding areas and was thoroughly integrated into the realities of the Roman Empire. Interregional contact and trade occurred freely, whilst resistance, even conflict, occurred due to the proximity of 'the Other' that threatened the cultural and religio-political sensitivities of the Galileans. This is typical of ethnic groups that allow for interethnic contact on certain matters, whilst resisting such contact on matters that were critical for group identity (cf. Harland 2003:196; Esler 1998:87). The Galileans were evidently also a people that had strong attachments to their Judean identity, as evidenced by their enhanced musical culture, conservative epigraphic habit, participation in the revolt and the following of cultural practices also found in Judea. Of course, the conservative nature of Galileans raises the question whether the 'openness to Gentiles' in the Jesus movement really originated in Galilee as Freyne suggests.

Other matters that need investigation are as follows: how and when did the region fall under Hasmonean control and what was the nature of the local population at the time? Were Galilean peasants experiencing harsh economic conditions through debt and taxation, or did the rule of Antipas allow for economic participation to flourish? The exact context of Jesus' ministry, therefore, is still a matter to be decided and invites further investigation. 


\section{Acknowledgements Competing interests}

The author declares that he has no financial or personal relationship(s) which may have inappropriately influenced him in writing this article.

\section{References}

Arav, R. \& Freund, R.A., 1997, 'Prize find: An incense shovel from Bethsaida', Biblical Archaeology Review 23(1) (BAR CD Archive: 1975-2001).

Arav, R., Freund, R.A. \& Shroder, J.F., 2000, 'Bethsaida rediscovered', Biblical Archaeology Review 26(1), 44-56.

Chancey, M.A., 2002, The myth of a Gentile Galilee, Cambridge University Press, Cambridge.

Cromhout, M., 2007, Jesus and identity: Reconstructing Judean ethnicity in Q, Cascade Books, Eugene, OR. (Matrix: The Bible in Mediterranean Context 2).

Cromhout, M., 2008, 'Were the Galileans 'religious Jews' or ethnic Judeans?', HTS Teologiese Studies/Theological Studies 64(3), 1279-1297.

Cromhout, M., 2010, Walking in their sandals: A guide to first-century CE Israelite ethnic identity, Cascade, Eugene, OR.

Duling, D.C., 2005, 'Ethnicity, ethnocentrism, and the Matthean ethnos', Biblical Theology Bulletin 35(4), 125-143.

Elliott, J.H., 2007, 'Jesus the Israelite was neither a 'Jew' nor a 'Christian': On correcting misleading nomenclature', Journal for the Study of the Historical Jesus, 5, 119-154.

Esler, P.F., 1998, Galatians, Routledge, London.

Esler, P.F., 2003, Conflict and identity in Romans: The social setting of Paul's letter Fortress Press, Minneapolis.

Fenton, S., 2003, Ethnicity, Polity, Cambridge.

Fiensy, D.A., 1991, The social history of Palestine in the Herodian period, The Edwin Mellen Press, Lewiston.

Freyne, S., 1988, Galilee, Jesus and the gospels: Literary approaches and historical investigations, Fortress Press, Philadelphia.

Freyne, S., 2001, 'The geography of restoration: Galilee-Jerusalem relations in early Jewish and Christian experience', New Testament Studies 47(3), 289-311.

Freyne, S., 2004, Jesus, a Jewish Galilean: A new reading of the Jesus-story, T\&T Clark, London.

Geertz, C., 2000, 'The integrative revolution: Primordial sentiments and civil politics in the new states,' in C. Geertz (ed.), The Interpretation of Cultures, pp. 255-310, Basic Books, New York.

Hanson, K.C., 1999, 'The Galilean fishing economy and the Jesus tradition', Biblical Theology Bulletin 27, 99-111.

Harland, P.A., 2003, Associations, synagogues, and congregations: Claiming a place in ancient Mediterranean society, Fortress Press, Minneapolis.

Hengel, M., 1989, The 'Hellenization' of Judaea in the first century after Christ, transl. J. Bowden, SCM Press, London.

Horsley, R.A., 1995, Galilee: History, politics, people, Trinity Press International, Valley Forge.
Horsley, R.A., 1996, Archaeology, history and society in Galilee: The social context of Jesus and the Rabbis, Trinity Press International, Valley Forge.

Horsley, R.A. \& Draper, J.A., 1999, Whoever hears you hears me: Prophets, performance, and tradition in $Q$, Trinity Press International, Harrisburg.

Jacobson, D., 2002, 'Herod's Roman Temple', Biblical Archaeology Review 28(2), 18-27, 60-61.

Malina, B.J., 1994, 'Religion in the imagined New Testament world: More social science lenses', Scriptura 51, 1-26.

Malina, B.J. \& Neyrey, J.H., 1996, Portraits of Paul: An archaeology of ancient personality, Westminster John Knox Press, Louisville.

Malina, B.J. \& Neyrey, J.H., 2008, 'Ancient Mediterranean persons in cultura perspective: Portrait of Paul', in J.H. Neyrey \& E.C. Stewart (eds.), The social world of the New Testament: Insights and models, pp. 257-275, Hendrickson Publishers, Peabody, MA.

Mason, S., 2009, Josephus, Judea, and Christian origins, methods and categories, Hendrickson, Peabody, MA.

McVann, M.S., 1993a, 'Change/novelty orientation', in J.J. Pilch \& B.J. Malina (eds.), Biblical social values and their meaning: A handbook, pp. 17-20, Hendrickson Publishers, Peabody.

McVann, M.S., 1993b, 'Compliance', in J.J. Pilch \& B.J. Malina (eds.), Biblical social values and their meaning: A handbook, pp. 31-33, Hendrickson Publishers, Peabody.

Neusner, J., 1984, In search of Talmudic biography: The problem of the attributed saying, Scholars Press, Chico.

Oakman, D.E., 2008, Jesus and the peasants, Cascade Books, Eugene, OR. (Matrix: The Bible in Mediterrannean Context).

Oppenheimer, A., 2005, Between Rome and Babylon, Mohr Siebeck, Tübingen.

Overman, J.A., Olive, J. \& Nelson, M., 2003, 'Discovering Herod's shrine to Augustus', Biblical Archaeology Review 29(2), 40-49, 67-68.

Pilch, J.J., 1997, 'Are there Jews and Christians in the Bible?', HTS Teologiese Studies/ Theological Studies 53(1/2), 119-125.

Porter, S.E., 1994, 'Jesus and the use of Greek in Galilee', in B. Chilton \& C.A. Evans (eds.), Studying the historical Jesus: Evaluations of the state of current research, pp. 123-154, EJ Brill, Leiden.

Reed, J.L., 1999, 'Galileans, "Israelite village communities", and the Sayings Gospel Q', in E.M. Meyers (ed.), Galilee through the centuries: Confluence of cultures, pp. 87-108, Eisenbrauns, Winona Lake.

Reed, J.L., 2000, Archaeology and the Galilean Jesus: A re-examination of the evidence, Trinity Press International, Harrisburg.

Richardson, P., 2004, Building Jewish in the Roman east, Baylor University Press, Waco.

Scott, G.M., 1990, 'A resynthesis of the primordial and circumstantial approaches to ethnic group solidarity: Towards and explanatory model', Ethnic and Racial Studies $13,147-171$.

Spivak, G.C., 1994, 'Can the Subaltern Speak?', in P. Williams \& L. Chrisman (eds.) Colonial Discourse and Post-Colonial Theory: A Reader, pp. 66-111,Columbia University Press, New York.

Stegemann, E.W. \& Stegemann, W., 1999, The Jesus movement: A social history of its first century, transl. O.C. Dean, T\&T Clark, Edinburgh.

Strange, J.F. \& Shanks, H., 1990, 'Synagogue where Jesus preached found at Capernaum', in H. Shanks \& D.P. Cole (eds.), Archaeology and the Bible: The best of BAR, vol. 2, Archaeology in the world of Herod, Jesus and Paul, pp. 200-207, Biblical Archaeology Society, Washington.

Zangenberg, J., Attridge, H.W. \& Martin, D.B. (eds.), 2007, Religion, ethnicity and identity in Ancient Galilee: A region in transition, Mohr Siebeck, Tübingen. (WUNT 210). 